\title{
Nitrogen Budget and Surface Water Nitrogen Load in a Chinese Watershed
}

\author{
Yongqiang Zhao ${ }^{1,2 *}$, Lvbing Jiang ${ }^{1}$, Yuguo $\mathrm{Wu}^{1}$ \\ ${ }^{1}$ College of Geography and Tourism, Zhengzhou Normal University, Zhengzhou 450044, China \\ ${ }^{2}$ State Key Laboratory of Soil and Sustainable Agriculture, Institute of Soil Science, \\ Chinese Academy of Sciences, Nanjing, 210008, China
}

Received: 25 June 2017

Accepted: 10 August 2017

\begin{abstract}
To assess the impact of human activity on the nitrogen $(\mathrm{N})$ cycle and evaluate the sources of $\mathrm{N}$ in surface water, the $\mathrm{N}$ budget for Laoguanhe River Watershed (LRW), a typical agricultural watershed and one of the upstream tributaries of Danjiangkou Reservoir in China, was developed by using measurement data on $\mathrm{N}$ fluxes and literature data on other parameters. Over the whole watershed, fertilizers, human and livestock excreta, atmospheric deposition, biotic fixation, $\mathrm{N}$ from crop residue used as fertilizer, and imported animal feeds contributed $65.7 \%, 20.7 \%, 6.1 \%, 5.6 \%, 1.7 \%$, and $0.3 \%$, respectively, to total $\mathrm{N}$ input $\left(40,816.6 \mathrm{~kg} \mathrm{~N} \mathrm{~km}^{-2}\right.$ year $\left.^{-1}\right)$. $\mathrm{N}$ transported to water bodies, denitrification, harvesting crops, and ammonia volatilization contributed $32.0 \%, 25.2 \%, 23.0 \%$, and $19.8 \%$ of total $\mathrm{N}$ output (21291.2 $\mathrm{kg} \mathrm{N} \mathrm{km}^{-2}$ year $)$, respectively. The $\mathrm{N}$ budget for the LRW suggested that more than $50 \%$ of the $\mathrm{N}$ input was lost to the environment, and about $17 \%$ was discharged as riverine $\mathrm{N}$, which indicated that agricultural and human activities in the watershed substantially impacted water quality, and so altered the $\mathrm{N}$ biogeochemistry process.
\end{abstract}

Keywords: nitrogen sources and exports, Middle Route of the South-to-North Water Diversion Project, Laoguanhe River, watershed budget

\section{Introduction}

Human activities such as fossil fuel burning, excessive use of nitrogen $(\mathrm{N})$, large-scale cultivation of $\mathrm{N}$-fixing plants, and intensive management of animal husbandry have led to a dramatic increase in global reactive $\mathrm{N}$ [1]. At present, human activities have more than tripled the global rate of $\mathrm{N}$ inputs to terrestrial ecosystems as compared to the pre-industrial era [2]. Excessive $\mathrm{N}$ loss during $\mathrm{N}$

*e-mail: zyongqiang@126.com use has caused significant impacts to the environment [3], such as air pollution, increased greenhouse gases, forest degradation, soil and freshwater acidification, and water eutrophication [1, 4]. Environmental problems caused by the increase of anthropogenic reactive $\mathrm{N}$ have become the third largest global environmentalsocial problem following the reduction of biodiversity and global warming [5]. Excessive $\mathrm{N}$ loading to surface water accelerates the growth of microbes that can deplete oxygen, destroy aquatic ecosystems, and result in eutrophication and hypoxia, and even dead zones [6-8]. It is difficult to mitigate $\mathrm{N}$ pollution in surface water once reactive $\mathrm{N}$ enters water bodies [9-10]. 
Therefore, understanding $\mathrm{N}$ emission sources and their influencing factors is a key first step to managing and mitigating water $\mathrm{N}$ pollution.

Chemical fertilizer and biological $\mathrm{N}$ fixation are the two main sources of global anthropogenic reactive $\mathrm{N}$ [1]. Therefore, the calculation of $\mathrm{N}$ balance in an agricultural ecosystem is one of the most important means and the basis for quantitatively understanding the $\mathrm{N}$ source and evaluating the environmental effect of N. China is the world's largest developing country, but also a large agricultural country. It is crucial to study the $\mathrm{N}$ balance in the agricultural watershed since that can fully reflect the whole process of nutrient transport in agricultural ecosystems. Understanding the sources and fate of excessive $\mathrm{N}$ at the watershed level not only contributes to scientifically understanding regional $\mathrm{N}$ balance and managing regional nutrient, but also to developing targeted measures to control the loss of $\mathrm{N}$ in the watershed, thereby reducing the significant impact on the regional ecological environment. However, in China studies on the $\mathrm{N}$ balance in agricultural watersheds are scarce and are mainly concentrated around the typical basin in southern China [4, 11-14].

Danjiangkou Reservoir is the water supplying area of the Middle Route of the South-to-North Water Diversion Project in China. The water quality safety of the reservoir area is related to the quality of life for the people in the water supply area. Since 2012, the Chinese government has targeted pollution and eutrophication control in the Danjiangkou Reservoir area. One of the most important targets was that the total $\mathrm{N}$ content of river discharges into the reservoir should meet grade III standards (i.e., National Surface Water Quality Standard GB3838-2002, $[\mathrm{TN}] \leq 2 \mathrm{mg} \mathrm{L}^{-1}$ ), since river inflow is the main source of pollutants to the reservoir [15]. However, even after years of comprehensive efforts, total $\mathrm{N}$ concentrations in some inflow rivers have not declined sufficiently to allow the ecosystem to rebalance. The agricultural non-point source pollution is one of the main reasons affecting the water quality of the reservoir area [9-10]. It is imperative to evaluate the source and fate of $\mathrm{N}$ in these inflow rivers to provide scientific and technological support for improving the water quality of Danjiangkou Reservior.

Laoguanhe River is one of the upstream tributaries of Danjiangkou Reservoir, which is an important water conservation area, the nearest upstream tributary to the Taocha diversion main canal. The Laoguanhe has been clearly identified as one of the key governance rivers in the 12th Five-Year Plan of water pollution control and soil and water conservation in the Danjiangkou Reservior and its upstream, since serious $\mathrm{N}$ pollution in the Laoguan includes TN concentrations of 2.6-3.0 mg $\mathrm{L}^{-1}$ [9]. However, none of studies established a complete $\mathrm{N}$ budget for LRW. In this study, we developed an $\mathrm{N}$ budget to provide a complete assessment on the sources and fates of $\mathrm{N}$ in LRW and a further understanding of the sources of $\mathrm{N}$ to the landscape and the associated $\mathrm{N}$ fluxes in the exports, and highlights research showing how anthropogenic activities impact $\mathrm{N}$ cycling in this typical agricultural watershed.

\section{Materials and Methods}

\author{
Study Area
}

Laoguanhe River is one of the upstream tributaries of Danjiangkou Reservoir, which is the nearest upstream tributary to the Taocha diversion main canal. The Laoguanhe is located in southwest Henan Province between longitude $111^{\circ} 01^{\prime} \sim 111^{\circ} 46^{\prime}$ and latitude $33^{\circ} 05^{\prime} \sim 33^{\circ} 48^{\prime}$. The Laoguan River has its origins in Luanchuan County and Lushi County, turns southeast and passes through Xixia County and Xichuan County before finally entering Danjiangkou. It has total length of $255 \mathrm{~km}$, basin area of $4,219 \mathrm{~km}^{2}$ (accounting for $2.5 \%$ of the total area of Henan Province), and naturally falls in bed elevation of $1,340 \mathrm{~m} ; 3,266 \mathrm{~km}^{2}$ belongs to the city of Nanyang. The Laoguanhe is a typical mountain river, and the $116 \mathrm{~km}$ head of the river is in the mountains with steep banks, and the forest coverage rate is about $90 \%$. The annual mean temperature of the study area is $16^{\circ} \mathrm{C}$, annual mean rainfall is $831 \mathrm{~mm}$, and annual average runoff is $6.6 \times 10^{8} \mathrm{~m}^{3}$.

The Laoguan River Watershed (LRW) is highly developed in agriculture and aquaculture. The human population was $188.3 \times 10^{4}$ persons, accounted for $1.8 \%$ of the total population of Henan Province. The average human population was 446.2 people $\mathrm{km}^{-2}$, which is much higher than the national average of 142.5 people $\mathrm{km}^{-2}$ [16]. Gross domestic product (GDP) in this area was $6,016,351 \times 10^{4}$ Yuan, accounting for $0.2 \%$ of the total GDP of Henan Province [17]. For LRW there is increasing impact on water quality due to the intensity of human activities in this region, plus anthropogenic $\mathrm{N}$ activation discharges from intensive agricultural activities and animal feeding [9, 18-19].

\section{Quantifying N Fluxes}

A biogeochemical budget was constructed for the LRW. The biogeochemical cycle of $\mathrm{N}$ in the watershed includes $\mathrm{N}$ input, output, and $\mathrm{N}$ surplus (i.e., $\mathrm{N}$ storage in the basin). We considered mineral fertilizers, atmospheric deposition, biological $\mathrm{N}$ fixation, import of feeds, and human and livestock excreta as sources of $\mathrm{N}$ input. $\mathrm{N}$ output included crop harvest, ammonia volatilization, $\mathrm{N}$ transport to water bodies, and denitrification. The surplus is equal to the difference between the input and the output of $\mathrm{N}$ in the basin.

All calculations were conducted for 2014. The basic data concerned in the $\mathrm{N}$ budget calculation were determined from the Henan Statistical Yearbook (2015) [17], the Nanyang Statistical Yearbook (2015) [20], the Luoyang Statistical Yearbook (2015) [21], and the Sanmenxia Statistical Yearbook (2015) [22], as well as literature values. 
Table 1. Coefficients for estimating the $\mathrm{N}$ budget.

\begin{tabular}{|c|c|c|c|}
\hline N sources & Items & $\begin{array}{c}\text { N contents } \\
\left(\mathrm{kg} \mathrm{N} \mathrm{ha}^{-1} \mathrm{year}^{-1}\right)\end{array}$ & References \\
\hline \multirow{4}{*}{$\begin{array}{c}\text { Biotic } \\
\text { fixation }\end{array}$} & Soybean & 105 & {$[24]$} \\
\cline { 2 - 4 } & Peanuts & 112 & {$[24]$} \\
\cline { 2 - 4 } & Paddy & 45 & {$[25]$} \\
\cline { 2 - 4 } & Other crops & 15 & {$[25]$} \\
\hline
\end{tabular}

\section{Calculating N Input}

\section{Fertilizers}

The four-county scale of statistical data of consumption of $\mathrm{N}$ fertilizer by $100 \%$ effective components was obtained from Nanyang Statistical Yearbook (2015) [20], Luoyang Statistical Yearbook (2015) [21], and Sanmenxia Statistical Yearbook (2015) [22]. Consumption of N fertilizer by $100 \%$ effective components is the conversion amount based on the average $\mathrm{N}$ content of the application amount of $\mathrm{N}$ fertilizer and compound fertilizer. The total amount of $\mathrm{N}$ input from fertilizers to the LRW was calculated by summation of the above county data.

\section{Atmospheric Deposition}

Input of $\mathrm{N}$ from total atmospheric deposition (dry and wet) was calculated following the method of Liu et al. [23]. In order to measure and estimate atmospheric $\mathrm{N}$ deposition, three observation sampling points were arranged in the village of Zhangying, the town of Shangji, and Xichuan County. Two self-made gauges (A and B) were installed at each observation site to continuously collect rainwater samples. One of the rain gauges (A) was used to collect the total settlement of the wet and dry disposition with a long-term open state. The other (B) was only to be opened before the start of the rain while it is usually covered with two layers of clean plastic bags, which are to be used only to collect the atmospheric wet deposition. The atmospheric dry settlement was considered the difference between $\mathrm{A}$ and $\mathrm{B}$. The monitoring experiment was conducted from September 2015 to August 2016. There were no point and line pollution sources such as tall trees, buildings, chimneys, high-traffic roads, etc., around the observation site $(30 \times 30 \mathrm{~m})$. After each rainfall event, the amount of rainfall was first recorded the next day at 09:00, and then a mixture of rain samples was collected, sealed, and transported to the laboratory on ice where different $\mathrm{N}$ species were measured. Based on the sum of monitored monthly data in each site, the annual atmospheric $\mathrm{N}$ deposition was interpolated and quantified for LRW according to Liu et al. [23].

\section{Biological N Fixation}

$\mathrm{N}$ inputs from biological fixation considered both symbiotic $\mathrm{N}$-fixation crops (peanut and soybean only, since
Table 2. Coefficients for estimating the import of seeds.

\begin{tabular}{|c|c|c|c|c|}
\hline $\begin{array}{c}\mathrm{N} \\
\text { sources }\end{array}$ & Items & $\begin{array}{l}\text { Seeding } \\
\text { amount } \\
\left(\mathrm{kg} \mathrm{ha}^{-1}\right)\end{array}$ & $\begin{array}{c}\mathrm{N} \\
\text { concentration } \\
(\%)\end{array}$ & Ref. \\
\hline \multirow{3}{*}{$\begin{array}{l}\text { Import } \\
\text { of seeds }\end{array}$} & Cereal & 30 & 1.78 & \multirow{3}{*}{ [26] } \\
\hline & Soybean & 67.5 & 5.30 & \\
\hline & $\begin{array}{c}\text { Oil-bearing } \\
\text { crops }\end{array}$ & 180 & 4.4 & \\
\hline
\end{tabular}

the area under other symbiotic $\mathrm{N}$-fixation crops was very small in the LRW) and non-symbiotic N-fixation crops in cropland areas. The $\mathrm{N}$ input from biological fixation was calculated by multiplying the $\mathrm{N}$-fixation rate for each crop type by the area of that crop in LRW. Data on the area of various crops were extracted from Nanyang Statistical Yearbook (2015) [20], Luoyang Statistical Yearbook (2015) [21], and Sanmenxia Statistical Yearbook (2015) [22]. Assumed average N-fixation rates of each crop are listed in Table 1. Total $\mathrm{N}$ inputs to agricultural lands from biological fixation were then estimated by multiplying the area of each crop by the relevant $\mathrm{N}$-fixation rates. There was no region-specific data for the nonsymbiotic $\mathrm{N}$ fixation rate of crops in China. The commonly used value of non-symbiotic $\mathrm{N}$ fixation rate was $4,500 \mathrm{~kg}$ $\mathrm{N} \mathrm{km}^{-2}$ year $^{-1}$ for rice and $1,500 \mathrm{~kg} \mathrm{~N} \mathrm{~km}^{-2}$ year $^{-1}$ for upland crops and vegetables [25]. We took these data as defaults to estimate the amount of non-symbiotic $\mathrm{N}$ fixation.

\section{Import of Seeds}

The $\mathrm{N}$ input from import feeds was calculated by multiplying the $\mathrm{N}$ concentration for each crop type, and seeding amount by the sown area of that crop in LRW. Data on the area of various crops were extracted from Nanyang Statistical Yearbook (2015) [20], Luoyang Statistical Yearbook (2015) [21], and Sanmenxia Statistical Yearbook (2015) [22]. The seeding amount and grain N concentration of various crops are shown in Table 2.

\section{Human and Animal Excreta}

The $\mathrm{N}$ input from human and animal excreta was calculated by multiplying the number of adult humans and livestock by the individual $\mathrm{N}$ production rate. We used a factor of 0.85 to calculate the $\mathrm{N}$ input from the corresponding adult population [25]. The numbers of pigs, cattle, sheep, and poultry were obtained from Nanyang Statistical Yearbook (2015) [20], Luoyang Statistical Yearbook (2015) [21], and Sanmenxia Statistical Yearbook (2015) [22]. The N production rates of adult humans and livestock were according to Xing and Yan [27] and Xing and Zhu [28] (Table 3).

\section{N from Crop Residue Used as Fertilizer}

Many kinds of crop residues are used as fertilizers for LRW soil because it is a large and developing agricultural 
Table 3. Annual $\mathrm{N}$ accumulation in human and animal excreta in LRW.

\begin{tabular}{|c|c|c|}
\hline Producer & $\begin{array}{c}\text { Rate }(\mathrm{kg} \mathrm{per} \mathrm{capita} \\
\left.\text { year }^{-1}\right)\end{array}$ & References \\
\hline Humans & 4 & \multirow{2}{*}{ [27-28] } \\
\cline { 1 - 2 } Cattle and other animals & 42 & \\
\cline { 1 - 2 } Pigs & 8 & \\
\cline { 1 - 2 } Sheep and goats & 7 & \\
\cline { 1 - 2 } Poultry & 0.6 & \\
\hline
\end{tabular}

region. However, the data on crop residues are not directly available. Therefore, the straw/seed ratio, the percentage of residues returned to the soil, and $\mathrm{N}$ concentration in crop residues was used to indirectly estimated the amount of $\mathrm{N}$ derived from crop residues. The crop harvest includes edible and non-edible portions. According to Xing and Zhu [26], about 38\% of the crop residues (nonedible portions) in the crop harvest would be returned to the farmland as fertilizer.

The amount of crop residues (non-edible parts) was calculated based on the straw/seed ratio according to Xing and Zhu [26], since we can only obtain the edible parts of crop yield in LRW from the Nanyang (2015) [20], Luoyang (2015) [21], and Sanmenxia (2015) [22] statistical yearbooks. The yield of each crop residue was first calculated, then the $\mathrm{N}$ contents of the corresponding crop residues were calculated according to the $\mathrm{N}$ concentrations in different crop portions of each crop [24], of which only $38 \%$ of crop residues were assumed to return to farmland.

\section{Calculation of N Output}

\section{Crop Harvest}

Crop harvest is the most important method of removing $\mathrm{N}$ from the agricultural system. In this study, the $\mathrm{N}$ output in terms of crop harvests was estimated using data on $\mathrm{N}$ concentrations in crop seeds (Table 4) and yield values, which were shipped out of the system. Harvest yield and shipped value was extracted from the Nanyang (2015) [20], Luoyang (2015) [21], and Sanmenxia (2015) [22] statistical yearbooks.

\section{$\mathrm{NH}_{3}$ Volatilization}

Ammonia volatilization included $\mathrm{NH}_{3}-\mathrm{N}$ emissions from chemical fertilizer, human and animal excreta, and background emissions. In calculating $\mathrm{N}$ losses through $\mathrm{NH}_{3}$ volatilization, we used the IPCC (1996) recommended default value $\left(0.20 \mathrm{~kg} \mathrm{~N} \mathrm{~kg}^{-1} \mathrm{~N}\right)$ as the conversion factor for human and animal wastes [27], and the averaged revised value from Xing and Zhu [28] as the conversion coefficients for fertilizers in paddy fields $(0.25$ $\left.\mathrm{kg} \mathrm{N} \mathrm{kg}^{-1} \mathrm{~N}\right)$ and upland $\left(0.09 \mathrm{~kg} \mathrm{~N} \mathrm{~kg}^{-1} \mathrm{~N}\right)$.
Table 4. Nitrogen concentrations in different crops and the ratio of straws/seeds.

\begin{tabular}{|c|c|c|c|}
\hline \multirow{2}{*}{ Crops } & \multicolumn{3}{|c|}{ N concentrations [24, 27] } \\
\cline { 2 - 4 } & Seeds & Straw & $\begin{array}{c}\text { Straw/Seed } \\
\text { (leaf/stem) }\end{array}$ \\
\hline Cereal & $1.53 \%$ & $0.64 \%$ & 1.2 \\
\hline Soybean & $5.11 \%$ & $2.01 \%$ & 1.6 \\
\hline Oil-bearing crops & $3.73 \%$ & $0.84 \%$ & 1.7 \\
\hline Vegetables & $0.50 \%$ & $0.50 \%$ & 0.5 \\
\hline
\end{tabular}

\section{Denitrification}

$\mathrm{N}$ losses due to denitrification were calculated using data from the statistical yearbooks [20-22], and the conversion factors for $\mathrm{N}$ losses through denitrification. Denitrification losses in the paddy field and upland were $32 \%$ and $15 \%$, respectively, and loss from manure was calculated as $13 \%$ of the manure $\mathrm{N}$ application [29].

\section{N Export to Surface Water}

As a typical agricultural basin, $\mathrm{N}$ export to surface water including the $\mathrm{N}$ leaching and runoff from $\mathrm{N}$ applied to agricultural fields, rural domestic sewage, and livestock excreta. The amount of $\mathrm{N}$ leaching and runoff from cropland in the region was calculated using the application amount of $\mathrm{N}$ fertilizer and the $\mathrm{N}$ loss rate of fertilizer. The $\mathrm{N}$ loss rate of fertilizer for runoff and leaching was 0.07 and 0.074 , respectively [26, 30]. Rural human and livestock excreta export to water bodies was estimated by the amount of $\mathrm{N}$ in excreta and the ratio of $\mathrm{N}$ that is transported to water. In this study, the value of 0.35 was used as the overall $\mathrm{N}$ loss ratio from rural human and livestock excreta [4].

\section{Results and Discussion}

\section{Sources of N Input}

The $\mathrm{N}$ budget was established as shown in Table 5 . Overall, on an annual basis, the amount of total $\mathrm{N}$ input in LRW was $172,205.1 \mathrm{t}$ in 2014, and the mean input rate of $\mathrm{N}$ was $40,816.6 \mathrm{~kg} \mathrm{~km}^{-2}$ year ${ }^{-1}$. Inputs from chemical fertilizer were heavy and averaged $26,802.2 \mathrm{~kg} \mathrm{~km}^{-2}$ year ${ }^{1}$, being the largest source of $\mathrm{N}$ input in the budget (65.7\%). Human and animal excreta contributed $20.7 \%$ to the total $\mathrm{N}$ input, and atmospheric $\mathrm{N}$ deposition contributed another $6.1 \%$. Average $\mathrm{N}$ input from seed import was $104.9 \mathrm{~kg} \mathrm{~km}^{-2}$ year ${ }^{-1}$, making it a minor contributor.

The total $\mathrm{N}$ input in this watershed was about 1.5 times that reported in the Yangtze River Delta region (29,100 kg km${ }^{-2}$ year $^{-1}$; Deng et al. [24]) and the Huaihe River basin (27,186 kg km-2 year-1; Zhang et al. [31]), and eight times that reported in mainland China $(5,013$ 
Table 5. Nitrogen budget for the Laoguan River Watershed.

\begin{tabular}{|c|c|c|c|}
\hline $\mathrm{N}$ budget & Ton $\mathrm{N}$ year ${ }^{-1}$ & $\begin{array}{c}\text { N Flux } \\
\left(\mathrm{kg} \mathrm{N} \mathrm{km}^{-2} \text { year }^{-1}\right)\end{array}$ & Percent of input (\%) \\
\hline \multicolumn{4}{|c|}{ Inputs } \\
\hline Fertilizers & $113,078.4$ & $26,802.2$ & 65.7 \\
\hline Atmospheric deposition & $10,463.1$ & $2,480.0$ & 6.1 \\
\hline Biological N fixation & $9,706.0$ & $2,300.6$ & 5.6 \\
\hline Import of seeds & 442.7 & 104.9 & 0.3 \\
\hline Human and animal excreta & $35,584.6$ & $8,434.4$ & 20.7 \\
\hline $\begin{array}{l}\mathrm{N} \text { from crop residue } \\
\text { used as fertilizer }\end{array}$ & $2,930.3$ & 694.5 & 1.7 \\
\hline Subtotal & $172,205.1$ & $40,816.6$ & 100.0 \\
\hline \multicolumn{4}{|c|}{ Outputs } \\
\hline Crop harvest & $20,642.7$ & $4,892.8$ & 12.0 \\
\hline Ammonia volatilization & $17,791.7$ & $4,217.0$ & 10.3 \\
\hline $\mathrm{N}$ export to surface water & $28,737.9$ & $6,811.5$ & 16.7 \\
\hline Denitrification & $22,655.3$ & $5,369.8$ & 13.2 \\
\hline Subtotal & $89,827.6$ & $21,291.2$ & 52.2 \\
\hline Budget & $82,377.5$ & $19,525.4$ & 47.8 \\
\hline
\end{tabular}

$\mathrm{kg} \mathrm{km}^{-2}$ year ${ }^{-1}$; Han et al. [32]). In addition, the input was also much higher than those reported for agricultural watersheds in the USA and Europe [33-35] (Table 6). The feature of heavy $\mathrm{N}$ input in the watershed was mainly attributed to developed agriculture and the high human population density. For developed agriculture leading to heavy chemical fertilizer input, the mean application rate of fertilizer was $26,802.2 \mathrm{~kg} \mathrm{~km}^{-2}$ year ${ }^{-1}$ in the watershed, which was about 1.8 times the average amount of $\mathrm{N}$ fertilizer application in China [16]. The heavy input of fertilizer $\mathrm{N}$ accordingly increased the high crop harvest, and resulted in increasing the amount of $\mathrm{N}$ in crop residues. It is noteworthy that the heavy chemical fertilizer application may bring about regional environmental problems since there is low $\mathrm{N}$ use efficiency in the LRW [36].

Followed by fertilizer application, rural human and animal excreta contributed $20.7 \%$ to total $\mathrm{N}$ inputs, with annual $\mathrm{N}$ fluxes of $8,434.4 \mathrm{~kg} \mathrm{~km}^{-2}$ year ${ }^{-1}$. The average human population was 446.20 people $\mathrm{km}^{-2}$ in this watershed, which is much higher than the national average of 142.48 people $\mathrm{km}^{-2}$ [16]. Additionally, animal husbandry has developed rapidly in recent years in the region, and most of them were loose housing breeding rather than intensive breeding, and $40 \%$ of wastewater of livestock was directly discharged without treatment [36]. The large population and massive amount of indiscriminate discharged of livestock sewage facilitated human and animal excrement, becoming another important source of $\mathrm{N}$ input in this watershed.

Our estimation showed that the average of atmospheric $\mathrm{N}$ deposition was $2,480 \mathrm{~kg} \mathrm{~km}^{-2}$ year ${ }^{-1}$, which contributed another $6.1 \%$ to total $\mathrm{N}$ inputs. The value was comparable to $\mathrm{N}$ deposition rates measured in the Yangtze River Delta [37], and was twice the national average $\left(1,289 \mathrm{~kg} \mathrm{~km}^{-2}\right.$ year $^{-1}$, Lü and Tian [38]). Rapid urbanization, fossil fuel combustion, denitrification, and ammonia volatilization in the watershed have all led to increasing the amount of $\mathrm{N}$ compounds in the atmosphere, causing $\mathrm{N}$ deposition to be another important source of $\mathrm{N}$ input.

\section{NOutput}

$\mathrm{N}$ output in this watershed mainly includes crop harvesting, ammonia volatilization, denitrification, and $\mathrm{N}$ transport to water bodies. The $\mathrm{N}$ output from the crop harvest would be consumed, burned, or returned to the farmland in the form of fertilizer $\mathrm{N}$, which will have a longterm effect on the environment. $\mathrm{NH}_{3}$, which is volatilized into the atmosphere as it is involved in the atmospheric chemical reaction, is then deposited in the cropland and water in the form of $\mathrm{NH}_{4}^{+}$and $\mathrm{NO}_{x}$, which has an effect on soil properties and water eutrophication. The processes of denitrification and ammonia volatilization would be conducted in the surface water when $\mathrm{N}$ was transported to water bodies through $\mathrm{N}$ leaching and runoff from agricultural fields, and rural human and livestock excreta. A full understanding of the $\mathrm{N}$ output of the agricultural watershed is of great significance to the prevention and control of severe $\mathrm{N}$ pollution.

Our estimated total $\mathrm{N}$ output was $89,827.6$ tons in 2014 and the mean output rate of $\mathrm{N}$ over the LRW was $21,292.2 \mathrm{~kg} \mathrm{~km}^{-2}$ year $^{-1}$ (Table 5). Among total $\mathrm{N}$ output from the LRW, $\mathrm{N}$ export to surface water was the 
Table 6. Comparisons of N input of LRW with other agricultural watersheds.

\begin{tabular}{|c|c|c|}
\hline Watershed & $\begin{array}{c}\text { Total N input } \\
\left(\mathrm{Kg} \mathrm{N} \mathrm{km}^{-2} \text { year }^{-1}\right)\end{array}$ & References \\
\hline This study & $40,816.6$ & {$[33]$} \\
\hline $\begin{array}{c}\text { The Big Ditch } \\
\text { Watershed } \\
\text { East-Central Illinois, } \\
\text { USA }\end{array}$ & 15,400 & {$[34]$} \\
\hline $\begin{array}{c}\text { Colousa Drain (COL), } \\
\text { California, USA }\end{array}$ & 4,359 & {$[34]$} \\
\hline $\begin{array}{c}\text { Tuolumne River } \\
\text { (TUO), California, } \\
\text { USA }\end{array}$ & 1,702 & {$[35]$} \\
\hline $\begin{array}{c}\text { The Centonara } \\
\text { Watershed, Bologna, } \\
\text { Italy }\end{array}$ & 3,360 & \\
\hline
\end{tabular}

largest source of $\mathrm{N}$ output in the budget, accounting for $16.7 \%$ of total $\mathrm{N}$ input. Denitrification and crop harvest respectively contributed $13.2 \%$ and $12.0 \%$ to the total $\mathrm{N}$ input in the watershed. $\mathrm{NH}_{3}$ volatilization from fertilizer and human and animal waste amounted to $4,217.0 \mathrm{~kg} \mathrm{~km}^{-2}$ year ${ }^{-1}$, or $10.3 \%$ of total $\mathrm{N}$ input.

Our estimated $\mathrm{N}$ export to surface water in the watershed was $28,737.9$ tons and $6,811.5 \mathrm{~kg} \mathrm{~km}^{-2}$ year 1. It is worth noting that not all $\mathrm{N}$ transported to water was discharged out of the watershed; a significant proportion of $\mathrm{N}$ in surface water should have been denitrified in the wetland systems, since denitrification is another important pathway of $\mathrm{N}$ output in the watershed. The process of denitrification has been implicated as an important subject of environmental concern for its role as the main biological process responsible for $\mathrm{N}_{2} \mathrm{O}$ and $\mathrm{NOx}$ production [39-40]. In LRW, the $\mathrm{N}$ output via denitrification accounted for $13.2 \%$ of total $\mathrm{N}$ input, and averaged $5,369.8 \mathrm{~kg} \mathrm{~km}^{-2}$ year ${ }^{-1}$. Most denitrification occurred in fertilizer $\mathrm{N}$ in croplands in LRW, where the denitrification rate was $4,020.3 \mathrm{~kg}$ $\mathrm{N} \mathrm{km}^{-2}$ year ${ }^{-1}$. The rate in this study is higher than the reported field experimental data elsewhere in China [24, $30,41]$. This can be explained as great denitrification variation among the different land uses and soils, as well as climate conditions. Therefore, from a watershed-scale management perspective, the reduction of $\mathrm{N}$ pollution in water bodies in LRW should not only focus on decreasing the amount of $\mathrm{N}$ input, but also on creating a suitable environment to improve the capacity of denitrification from water bodies such as ecological remediation of rivers or creating and restoring wetlands and riparian buffer strips [42].

The $\mathrm{N}$ output from crop harvest was 20,642.7 tons, averaging 4,892.8 $\mathrm{kg} \mathrm{N} \mathrm{km}^{-2}$ year $^{-1}$ and accounting for $12.0 \%$ of the total $\mathrm{N}$ input. This part of output $\mathrm{N}$ will be consumed by humans and animals, and then transported to the surface water in the form of human and animal excreta, which may lead to water pollution.
Because of the heavy chemical $\mathrm{N}$ fertilizer application and high human and animal population density, $\mathrm{NH}_{3}$ volatilization in this watershed accounts for $10.3 \%$ of the total $\mathrm{N}$ input, averaging $4,217.0 \mathrm{~kg} \mathrm{~N} \mathrm{~km}^{-2}$ year $^{-1}$, which was comparable with that in the Jiulong River Watershed [41]. Ammonia gas is pretty reactive during its transport in the atmosphere, and competes with the important greenhouse gas $\mathrm{CH}_{4}$ for hydroxyl, hindering the oxidation of $\mathrm{CH}_{4}$ and settling to the land of $\mathrm{NH}_{4}$ to acidify the soil, reducing biodiversity, and becoming a secondary source of $\mathrm{N}_{2} \mathrm{O}$. Therefore, it is also an important source of $\mathrm{N}$ pollution in the atmospheric environment.

Based on the output structure, environmental emissions was the most important form of $\mathrm{N}$ output, and about $69,184.9$ tons of $\mathrm{N}$ ( $77 \%$ of total $\mathrm{N}$ output) were discharged into the atmosphere and surface water in LRW in 2014 (Table 5). Undoubtedly, the massive amount of $\mathrm{N}$ emissions could bring about serious environmental problems in the watershed.

\section{N Budget}

We constructed $\mathrm{N}$ budgets by calculating the difference between all inputs of $\mathrm{N}$ and all outputs of $\mathrm{N}$. The $\mathrm{N}$ budget for the LRW was positive, with inputs exceeding outputs by $82,377.5 \mathrm{t}$, with a high fraction (47.8\%) of total $\mathrm{N}$ input (Table 5). The $\mathrm{N}$ inputs/outputs patterns of each watershed vary widely, but inputs were consistently higher than outputs in agricultural watersheds [12, 34-35, 37, 41].

\section{Sources of N Load to Water Bodies}

$\mathrm{N}$ applied to croplands has been blamed as the major source of $\mathrm{N}$ in surface water in the agricultural watershed. For example, Gentry et al. [33] estimated that $50 \%$ of the fertilizer $\mathrm{N}$ applied was discharged into surface water in the Big Ditch watershed. Our calculations showed that the largest source of $\mathrm{N}$ load in the surface water of LRW was rural human and livestock excreta, accounting for $43.3 \%$ of the total load. Our result is consistent with the finding of Liu et al. [43] and Bao et al. [30] - that about $60 \%$ of excreted $\mathrm{N}$ from humans and livestock were discharged directly into rivers in the Changjiang River Basin. $\mathrm{N}$ runoff and leaching from $\mathrm{N}$ applied to agricultural fields contributed 29.1 and $27.5 \%$, respectively. With an increase of $\mathrm{N}$ transport to water bodies, $\mathrm{N}$ pollution of water bodies, one of the most serious environmental issues, has already had a significant effect on water quality within the LRW $[9,36]$. It is therefore critical to improve the treatment ratio and efficiency of waste to mitigate $\mathrm{N}$ concentration in LRW surface water.

In our budget, the calculated amount of $\mathrm{N}$ transported into water bodies should be considerably larger than the riverine $\mathrm{N}$ flux at the outlet of each basin, since a significant portion of $\mathrm{N}$ was expected to be consumed by biological, chemical, and physical processes on land and in the rivers. The amount of riverine $\mathrm{N}$ output was 
flow-weighted and estimated by multiplying a measured concentration of TN in the Laoguan River outlet. The monthly water $\mathrm{N}$ concentrations and flow fluxes in the Laoguan were monitored by Wang et al. [9], in which $\mathrm{TN}$ concentrations ranged from 2.6-3.0 $\mathrm{mgL}^{-1}$, the amount of $\mathrm{N}$ output from the Laoguan was about $3,820.7 \mathrm{t}$ in 2014. We took these data as the amount of $\mathrm{N}$ runoff from water bodies in LRW. Compared with the estimated riverine TN flux, a total of 28,737.9 tons of $\mathrm{N}$ transported into water bodies was estimated for the LRW (Table 5), indicating that about 24,917.2 $\mathrm{t} \mathrm{N}$ (or $86.7 \%$ of $\mathrm{N}$ ) was consumed or stored by watershed processes.

The $\mathrm{N}$ budget for the LRW indicated that about $16.7 \%$ of $\mathrm{N}$ input was transported to the surface water. The values are comparable with those reported in the Jiulong River watershed (about $14 \%$ of the $\mathrm{N}$ input), and in American and European river watersheds (range 1-45\%; [35, 42]). For the low fraction of riverine $\mathrm{N}$ export compared to other regions, the authors argued that there should be a considerable deposition to sediment and assimilation to plants, as well as other biogeochemistry processes in this watershed, which resulted in a decreasing actual $\mathrm{N}$ output through runoff in the LRW.

\section{Conclusions}

Our $\mathrm{N}$ budget calculation showed that total $\mathrm{N}$ input was up to $40,816.6 \mathrm{~kg} \mathrm{~N} \mathrm{~km}^{-2}$ year-1, with fertilizers, human and livestock excreta, atmospheric deposition, biotic fixation, $\mathrm{N}$ from crop residue used as fertilizer, and import of animal feeds contributing $65.7 \%, 20.7 \%$, $6.1 \%, 5.6 \%, 1.7 \%$, and $0.3 \%$, respectively. $\mathrm{N}$ transported to water bodies, denitrification, crop harvesting, and ammonia volatilization contributed $32.0 \%, 25.2 \%$, $23.0 \%$, and $19.8 \%$ of total $\mathrm{N}$ output $(89,827.6$ ton $\mathrm{N}$, $21,291.2 \mathrm{~kg} \mathrm{~N} \mathrm{~km}^{-2}$ year $^{-1}$ ), respectively. The $\mathrm{N}$ budget for the LRW suggested that more than $50 \%$ of $\mathrm{N}$ input was lost to the environment (air and water), and about $17 \%$ was discharged as riverine $\mathrm{N}$, which indicated that agricultural and human activities in the watershed substantially impacted the surface water quality, and so altered the $\mathrm{N}$ biogeochemistry cycle. Understanding $\mathrm{N}$ sources and exports at the watershed scale can provide a knowledge base for remediation of diffuse agricultural pollution, but further studies are still needed regarding biogeochemical behavior within the watershed, and the retention of $\mathrm{N}$ in the soil and groundwater.

\section{Acknowledgements}

This work was jointly supported by the Open Fund of the State Key Laboratory of Soil and Sustainable Agriculture (Y20160036), the Key Scientific Research Projects of Higher Education of Henan Province (17A210031), and the Project of Science and Technology of Henan Province (172102310735).

\section{References}

1. GALLOWAY J.N., DENTENER F.J., CAPONE D.G., BOYER E.W., HOWARTH R.W., SEITZINGER S.P., ASNER G.P., CLEVELAND C.C., GREEN P.A., HOLLANDE.A., KARL D.M., MICHAELS A.F., PORTER J.H., TOWNSEND A.R., Vörösmarty C.J. Nitrogen cycles: Past, present, and future. Biogeochemistry, 70, 153, 2004.

2. FOWLER D., COYLE M., SKIBA U., SUTTON M.A., CAPE J.N., REIS S., SHEPPARD L.J., JENKINS A., GRIZZETTI B., GALLOWAY J.N. The global nitrogen cycle in the twenty-first century. Trans R Soc B, 368, 20130164, 2013.

3. ERISMAN J.W., GALLOWAY J.N., SEITZINGER S., BLEEKER A., DISE N.B., PETRESCU A.M.R., LEACH A.M., DE VRIES W. Consequences of human modification of the global nitrogen cycle. Phil Trans R Soc B, 368 (1621), 20130116, 2013.

4. GU B., JU X., CHANG J., GE Y., Vitousek P.M. Integrated reactive nitrogen budgets and future trends in China. PNAS, 112 (28), 8792, 2015.

5. GILES J. Nitrogen study fertilizes fears of pollution. Nature, 433 (7028), 791, 2005.

6. FUNKEY C.P., CONLEY D.J., REUSS N.S., HUMBORG C., JILBERT T., SLOMP C.P. Hypoxia sustains cyanobacteria blooms in the Baltic sea. Environ Sci Technol, 48, 2598e2602, 2014.

7. GLIBERT P.M., MARANGER R., SOBOTA D.J., BOUWMAN L. The Haber Boscheharmful algal bloom (HBeHAB) link. Environ Res Lett, 9, 105001, 2014.

8. GUO L. Doing battle with the green monster of Taihu Lake. Science, 317, 1166, 2007.

9. WANG S., WANG W., JIANG X., ZHAO L., ZHANG B., WU D., CHANG L. Spatial and temporal distribution and flux of nitrogen in water of Danjiangkou ReservoirResearch of Environmental Sciences, 29 (7), 995, 2016 [In Chinese].

10. WEI C., SONG X., CHEN J. Sensitivity analysis of SWAT model on changes of landscape pattern: a case study from Lao Guanhe watershed in Danjiangkou reservoir area. Acta Ecologica Sinica, 34 (2), 517, 2014 [In Chinese].

11. GU B., LEACH A.M., MA L., GALLOWAY J.N., CHANG S.X., GE Y., CHANG J. Nitrogen footprint in China: food, energy and nonfood goods. Environ Sci Technol, 47, 9217, 2013.

12. TI C., XIA Y., PAN J., GU G., YAN X. Nitrogen budget and surface water nitrogen load in Changshu: a case study in the Taihu Lake region of China. Nutr Cycl Agroecosyst, 91, 55, 2011.

13. TI C.P., YAN X.Y. Spatial and temporal variations of river nitrogen exports from major basins in China. Environ Sci Pollut R, 20, 6509, 2013.

14. YAN X.Y., CAI Z.C., YANG R., TI C.P., XIA Y.Q., LI F.Y., WANG J.Q., MA A.J. Nitrogen budget and riverine nitrogen output in a rice paddy dominated agricultural watershed in eastern China. Biogeochemistry, 106, 489, 2011.

15. The $12^{\text {th }}$ Five-Year Plan of water pollution control and soil and water conservation in the Danjiangkou Reservior and its upstream. Available online: http://www.henan.gov.cn/ zwgk/system/2013/09/22/010425568.shtml (accessed on 16 Mar 2017) [In Chinese].

16. CHINA STATISTICAL YEARBOOK. Edited by National Bureau of Statistics of China, China Statistic Press, Beijing, 2015 [In Chinese]. 
17. HENAN STATISTICAL YEARBOOK. Henan Satistical Bureau. China Statistic Press, Beijing, 2015 [In Chinese].

18. BORTHWICK A., LIU R., ZHANG K., ZHANG Z.J. Watershed-scale environmental risk assessment of accidental water pollution: the case of Laoguan River, China. J Environ Inform, 2016.

19. WANG G., ZUO H., WEI J., HUANG Y. Identifying critical source areas for agricultural non-point source pollution in Laoguanhe Watershed of Middle Route of the South-toNorth Water Diversion Project. Earth Science Frontiers, 17 (6), 13, 2010 [In Chinese].

20. NANYANG STATISTICAL YEARBOOK. Nanyang Satistical Bureau. China Statistic Press, Beijing, 2015 [In Chinese].

21. LUOYANG STATISTICAL YEARBOOK. Luoyang Satistical Bureau. China Statistic Press, Beijing, 2015 [In Chinese].

22. SANMENXIA STATISTICAL YEARBOOK. Sanmenxia Satistical Bureau. China Statistic Press, Beijing, 2015 [In Chinese].

23. LIU D.B., ZHANG X.Y., BA R.X., LIU Y., FAN X.P., ZHANG F.L., XIONG G.Y. Atmospheric nitrogen deposition in Danjiangkou Reservoir area of Northwest Hubei. Acta Ecologica Sinica, 35 (10), 3419, 2015.

24. DENG M.H., XIE Y.X., XIONG Z.Q., XING G.X., YAN X.Y. Nitrogen budgets of the Yangtse delta region and their effect on the environment. Acta Scientise Circumstantise, 27 (10), 1709, 2007 [In Chinese].

25. ZHU Z.L. Nitrogen balance and cycling in agroecosystems of China. In: ZHU Z.L., WEN Q.X., FRENEY J.R., Eds., Nitrogen in soils of China. Kluwer, The Netherlands, 323, 1997.

26. XING G.X., ZHU Z.L. Regional nitrogen budgets for China and its major watersheds. Biogeochemistry, 57, 405, 2002.

27. XING G.X., YAN X.Y. Direct nitrous oxide emissions from agricultural fields in China estimated by the revised (1996) IPPC guidelines for national greenhouse gases. Environ Sci Policy, 2, 355, 1999.

28. XING G., ZHU Z. An assessment of Nitrogen loss from agricultural fields to the environment in China. Nutr Cycl Agroecosyst, 57, 67, 2000.

29. CHEN M., CHEN J. Nitrogen flow in farmingfeeding system and its environmental impact in China. Environmental Science, 28 (10), 2342, 2007 [In Chinese].

30. BAO X.,WATANABEE M.,WANG, Q., HAYASHI S., LIU J. Nitrogen budgets of agricultural fields of the Changjiang River basin from 1980 to 1990, Sci Total Environ, 363, 136, 2006.
31. ZHANG W.S., SWANEY D.P., LI X.Y., HONG B., WOWARTH R.W., DING S.H. Anthropogenic point-source and non-point-source nitrogen inputs into Huai River basin and their impacts on riverine ammonia-nitrogen flux. Biogeosciences, 12, 4275, 2015.

32. HAN Y., FAN Y., YANG P., WANNG X., WANG Y., TIAN J., XU L., WANG C. Net anthropogenic nitrogen inputs (NANI) index application in Mainland China. Geoderma 213, 87, 2014

33. GENTRY L.E., DAVID M.B., BELOW F.E., ROYER T.V., MCLSAAC G.F. Nitrogen mass balance of a tile-drained agricultural watershed in east-central Illinois. J Environ Qual, 38 (5), 1841, 2009.

34. SOBOTA D.J., HARRISON J.A., DAHLGREN R.A. Influences of climate, hydrology, and land use on input and export of nitrogen in California watersheds. Biogeochemistry 94, 43, 2009.

35. PIERI L., VENTURA F., VIGNUDELLI M., ROSSI P. Nitrogen balance in a hilly semi-agricultural watershed in Northern Italy. Ital J Agron, 6 (1), 67, 2011.

36. CHEN J., DING W., XU G., HU L., JIA H., ZHAO Q. The investigation of total nitrogen pollution in Danjiangkou reservoir of Henan. Environmental Monitoring in China, 26 (2), 49, 2010 [In Chinese].

37. ZHAO X., YAN X.Y., XIONG Z.Q., XIE Y.X., XIG G.X., SHU S.L., ZHU Z.L. Spatial and temporal variation of inorganic nitrogen wet deposition to the Yangtze River Delta Region, China. Water Air Soil Pollut, 203, 277, 2009.

38. LÜ C.Q., TIAN H.Q. Spatial and temporal patterns of nitrogen deposition in China: synthesis of observational data. J Geophys Res, 112 (D22S05), 1, 2007.

39. KNOWLES R. Denitrification. Microbiol Rev, 46, 43, 1982.

40. ČUHEL J., ŠIMEK M., LAUGHLIN R.J., BRU D., CHENEBY D., EATSON C.J., PHILIPOT L. Insights into the effect of soil $\mathrm{pH}$ on $\mathrm{N}_{2} \mathrm{O}$ and $\mathrm{N}_{2}$ emissions and denitrifier community size and activity. Appl Environ Microbiol, 76 (6), 1870, 2010

41. CHEN N.W., HONG H.S., ZHANG L.P., CAO W.Z. Nitrogen sources and exports in an agricultural watershed in Southeast China. Biogeochemistry, 87, 169, 2008.

42. BOYER E.W., GOODALE C.L., JAWORSKI N.A., HOWARTH R.W. Anthropogenic nitrogen sources and relationships to riverine nitrogen export in the northeastern USA. Biogeochemistry, 57, 137, 2002.

43. LIU C., WATANABE M., WANG Q.X. Changes in nitrogen budgets and nitrogen use effi ciency in the agroecosystems of the Changjiang River basin between 1980 and 2000. Nutr Cycl Agroecosyst, 80, 19, 2008. 